\title{
INFLUENCE OF TALENT ATTRACTION ON ORGANISATIONAL PERFORMANCE IN PUBLIC UNIVERSITY CAMPUSES IN COUNTY GOVERNMENT OF NAKURU, KENYA
}

\author{
Lydia J. Rop \\ Egerton University (Administration Division), Kenya. \\ Josphat W. Kwasira \\ School of Entreprenuership, Procurement \& Management \\ Jomo Kenyatta University of Agriculture and Technology, Kenya
}

\begin{abstract}
Public universities in Kenya are operating in an environment which is faced with a lot of competition. This is because over the years the number of Universities has drastically increased and there has been advancement in technology bringing about shortage of talent. Institutions are increasingly looking at talent as a unique asset that can provide sustainable competitive advantage and superior performance. This research sought to establish the influence of talent attraction on organizational performance. The study was guided by Maslows theory. The target population for the study was; managers, academic staff and non-academic staff in campuses of public universities in county government of Nakuru, Kenya. Stratified random sampling and simple random sampling techniques were used to determine the sample of each stratum of various sub population of total sample unit size of 102. Structured questionnaire was used to collect data. The instrument was pilot tested to ascertain the reliability of the research instrument using Cronbach Alpha. The reliability of the research instrument was found to be 0.794 which was considered reliable. The study employed both descriptive and inferential statistics to present and analyze the data. The Statistical Package for Social Science (SPSS) a computer programme for windows aided the data analysis. The study established that talent attraction showed strong positive relationship against organizational performance in Public University Campuses in County Government of Nakuru with correlation of $(r=0.640, p<0.05)$. The study recommends that HR departments to be responsive to needs and constantly changing requirements of workforce in order to improve programmes and policies as need may be. It is also important that institutions adopt talent management to improve on its performance. The study also recommends that further research could be carried out in private universities to establish the differences.
\end{abstract}

Key words: Talent Attraction, Talent Management, Organizational Performance, Nakuru County.

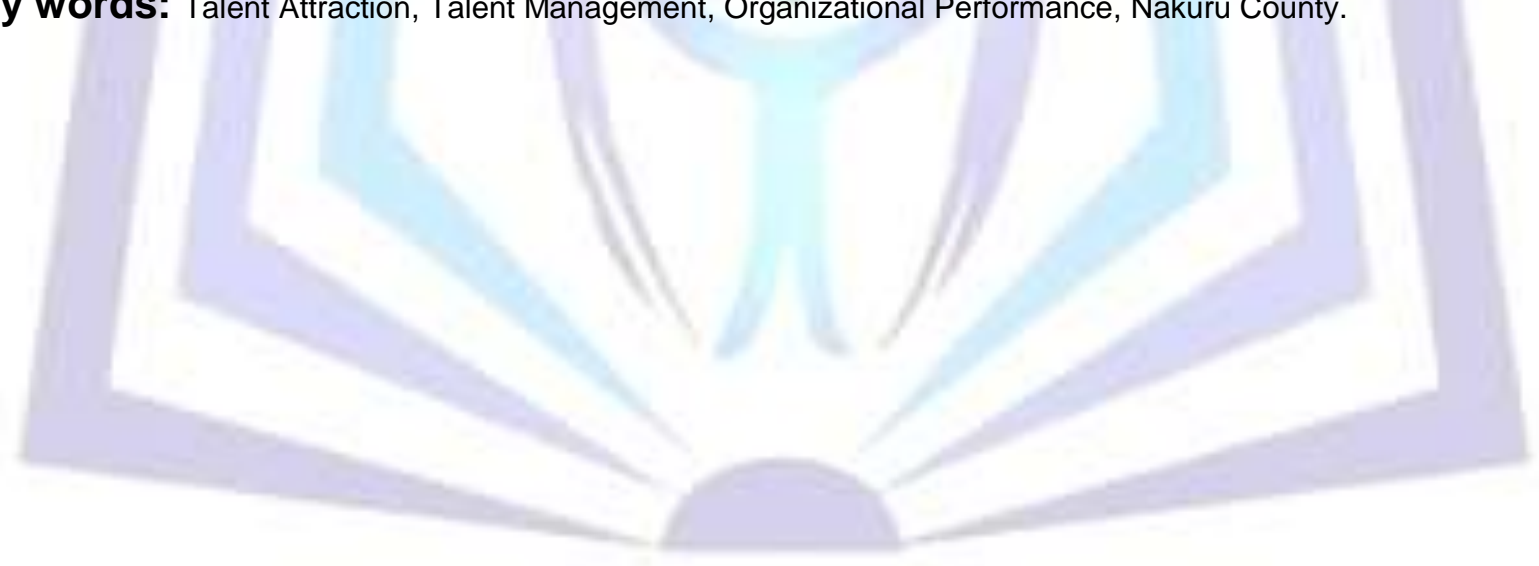

\section{Council for Innovative Research}

Peer Review Research Publishing System

\section{Journal: International Journal Of Management \& Information Technology}

\author{
Vol. 10, No 8 \\ editorsijmit@gmail.com \\ www.ijmit.com




\subsection{Introduction}

In the current organizations talent management plays a key role towards their success. Organizations have assets like technologies, products, and strategies which can be duplicated by other institutions but human capital takes some time to develop and is considered as an important asset which gives an organization competitive advantage (Onwuka, Enyinna \& Ezinne, 2015). The need therefore to have talented employees occupy strategic positions is key hence organizations are exposed to continuous competition for the best talent. Bano, Khan, Rehman \& Humayoun (2011) argued that talent management differs from other human resources approaches because it is about identifying key positions which needs to be filled with "A" performers. With the right talent management strategy, the company will become a learning company where employees are 'knowledge workers', it means that they have the knowledge required to do a very good job, but it also means that they can learn quickly and apply the knowledge in a practical and effective way, finally they have the ability to transfer the knowledge to others Rahimli, (2012).

The concept of talent management as a process of ensuring that the organization has the right people it requires emerged in the late 1990's when Mc Kinsey consultant coined the war of talent to underscore the key role of leaders and high potentials played in the success of leading companies (Scullion et al, 2010). Talent management is complex and continually evolving and is influenced by external factors such as the economy global expansion, mergers and acquisitions. There are important factors for effective talent management which include alignment with strategic goals, active Chief Executive Officers (CEO) participation and human resource management.

Talent management is the systematic attraction, identification, development, engagements/ retention and deployment of those individuals who are of particular value to an organization either in view high potential for the future or because they are fulfilling business/ critical roles. Talent is the primary driver for any successful organization. This has led to most organizations to be constrained by talent rather than capital. (Kehinde, 2012). Talent management systems have failed in many institutions due to lack of planning and implementation of management policies, processes, and programs which have positive impact on the process of acquiring, developing and retaining talents to sustain organizational competitive advantage ( Onwuka et al, 2015).

The emergence of globalization brought about stiff competition between international companies for skilled labour force. Organizations would hire their staff externally without considering their internal staff to fill certain positions. This therefore implied that they sourced their talent from their rivals in the market which brought in many problems (FakhrEIDin, 2013). Having the right people in the right position to perform certain functions is crucial for institutions globally. Organizations have therefore learned that at any given time you need the right talent to execute a function depending on what your business strategy is. Organizations around the world are competing for the same pool of talent. This is seen as global labour markets for talent (Kehinde, 2012). For organizations around the globe, talent management of knowledge workers and high potentials is of increasing strategic importance. It is likely to be a challenge for organizations in all the major economies right across the world with recent research suggesting that talent management challenges may even be more acute in the emerging markets (Veiman \& Holden, 2011).

Most African countries have lost their talented employees to other countries like Canada, France, U.K Australia and the Gulf states. As a result universities depend on individuals who have not acquired their highest level of training. It has become the top agenda of most CEO's in Africa to come up with strategies to manage talent as lack of the required talent is becoming a threat to the organizational growth (Kamau et al, 2013). The African association for Public administration and management (AAPAM), found out that African continent has not been able to recruit and retain the required well trained and skilled personnel due to challenges which include poor compensation and uncompetitive working environment. Due to such factors it has led to high labour turnover in institutions of higher learning hence affecting on their performance (AAPAM, 2008). According to Kamau et al, (2013), the most critical element to be given attention in institution of higher learning is the human capital which includes academic, administrative, and technical staff resources. However most developed countries are engaged in the struggle on how to attract and retain talent to reduce brain drain.

According to business review management (2013), Kenya faces the challenge of shortage of talent. This shortage is felt at both the professional and non-professional management in Kenya. Most Universities in Kenya are relying on individuals who have not achieved the highest level of education as lecturers therefore making the quality of graduates questionable. It is therefore important that universities manage talent properly to ensure that it competes effectively and also to produce quality graduates (Kamau et al, 2013). Gichuhi et al, 2014, pointed out that organizations must have the best talent in order to succeed in the hypercompetitive and increasingly complex economy. Besides hiring, developing and retaining talented people, organizations are aware that they must manage talent as a critical resource to achieve the best possible results. Kenani, (2011) argued that there seemed to be need for increasing scientific knowledge and skills of the employees at geothermal companies in Kenya. Human resource management needs to put more emphasis on the productive development and use of people in the company to collectively achieve the organization's strategic business objectives.

Talent management has many variables which include; learning and development, career development, recruitment selection, attraction, retention, motivation, mentoring programs, succession management amongst others. This study will focus on talent attraction. Talent attraction involves recruitment, selection and employer branding. Employees could either be sourced internally or externally. When an institution therefore is in a position to have the right candidates through the use of talent search matrix then it is assured of competing effectively in the market (Lyria, 2013).

Organizational performance is the organizations ability to attain its goals by using resources in an efficient and effective manner. It is also the ability of organization to achieve its goals and objective (Jarad, Yusof \& Nibkin 2010). On the other 
hand, Khatari, Gupta, Gulati \& Chauhan (2010), argues that in many leading organizations, management establishes the necessary parameters to ensure that an organization has the right person with the right skills in the right job at the right time to reach strategic goals at all times hence impacting on organizational performance. According to Lyria, (2013), talent that is an organizations employee's typically is the single biggest lever for driving improvements in institutions performance. Achieving sustained organizational performance through the development of a capable workforce lies in the very heart of talent management. According to Lyria (2013), there are various methods of measuring performance in an organization which can be categorized as follows; customer satisfaction, service delivery, operational performance, employee satisfaction and learning and growth. Talent management can provide competitive advantage to organizations. Organization's talent injects capabilities that are difficult for competitors to replicate and benchmark. In comparison to all other assets in organizations, talent provides long term competitive advantage. $73 \%$ of executives in USA agree on the positive relationship between talent management and business strategy to obtain the success of the organization (Mohammed \& Mochorwa, 2015).

\subsection{Statement of the Problem}

Universities being the centre for research call for need of having talent management. Through talent, universities are able to become more creative and innovative. One of the major limiting factors is financial resource. In the 2014/2015 financial year, the Kenyan government allocated only $2 \%$ of its annual budget to research this hinders innovation. A report by GOK (2010) and BCG (2007) indicate that the public sector experiences difficulties in recruitment \& retaining employees particularly where they compete with private firms for skilled and talent workers. It is noted that the private sector has placed much emphasis on talent management by allocating sufficient resources. Some of the Universities have initiated a number of programs to enhance talent management. Kenyatta University for example has come up with a well-equipped innovation center under the name of a prominent individual by the name Chandaria as a way of attracting and retaining some of the best talent. But still much has to be done in public universities in Kenya to ensure that it is able to attract and retain the best talent. According to Veiman \& Holder (2011), although talent management plays a greater role within the public sector little research has been done on how public institutions have tackled the issue. This research therefore will establish the influence of talent attraction on organizational performance.

\subsection{Purpose and Objective of the Study}

To establish the influence of talent attraction on Organizational Performance in Public University Campuses in County Government of Nakuru, Kenya

\subsection{Research Questions}

What is the influence of talent attraction on organizational performance in Public University campuses in county government of Nakuru, Kenya?

\subsection{LITERATURE REVIEW}

\subsection{THEORETICAL REVIEW}

This study was guided by Maslows Hierarchy Theory.

\subsubsection{Maslows Hierarchy Theory}

According to Maslow theory people have some needs because they are social and psychological entities and that people have to satisfy these needs. Maslow's ideas would help managers in institutions to understand the needs of its employees and to determine what to be done to satisfy them (Ozguner, 2014). Saleemi, (2006) argued that an organization can help individuals satisfy their needs by providing good pay, proper working conditions and other benefits. According to Lyria (2013), once the physiological needs are satisfied, safety needs become significant. These needs consist of physical safety or protection against fire, accident and economic securities against unemployment. An organization can influence safety needs by providing job security, pension plans, Insurance plans, safe and healthy working conditions. Hierarchy is the social needs; man is a social being, therefore he has a need to belong and to be accepted by others.

Social needs include need for love and affection, association with and acceptance by various social groups (Saleemi, 2006). It could therefore be inferred that employees can be attracted to work for an organization that satisfies their social needs by having good work -life balance as well as having good social net-working (Kelly, 2013). Self esteem involve how others see us at work and can be enhanced by working for an organization with good employer brand and allowing employees to gain qualification at work. In addition, employees would be attracted to work for organizations that give them room to grow to their full potential thus realizing self actualization (Mwangi, 2013).

\subsubsection{Talent Attraction and Organizational Performance}

In an era where skills and knowledge of employees gives an organization competitive advantage, the importance of attracting and retaining the talented workforce cannot be overlooked (Minchington, 2010). Talent attraction is composed of recruitment and selection, employer branding, employee value preposition and employer of choice (Armstrong, 2011). Human resource departments should also consider flexible working hours as a strategy for attracting key talent. Employer branding involves a set of activities which would help an organization attract the potential employees. It makes an organization more attractive for job seekers therefore an organization makes less effort to develop its talent. Organizational attractiveness is considered to give an organization competitive advantage (Yagub \& Khan 2011). lles and 
Preece 2010 argued that employees need to brand themselves as employers of choice through having a good image in terms of employee working conditions and rewards.

Sokro, 2012 studied the impact of employee branding on employee attraction and retention found out that branding has become a major tool for organizations to attract quality employees in their organizations. According to Botha and Swarth (2011), in their study on employer brand predictive model for talent attraction and retention found out that employers who established target group needs first were able to attract and talented employees. Communication of employer brand message was also an important determinant of whether the right job seekers would be attracted in the organization. In recruitment the first process is to attract the talent pool with special traits. This could either be sourced internally or externally. Attracting internally is a preferred option since most of these employees have knowledge on the working of the organization. External attraction would be preferable when an organization wants to introduce radical change (Lyria, 2013)

According to Kelly, (2013) survey on businesses involved in Finance, Engineering, Information Technology he found out that the major components of talent attraction included salary packages benefits, recruitment styles, work life balance and social networking. Line managers are key in the stage of talent attraction. This is because line managers interact with employees on a daily basis and their relationship therefore determines the employee duration in an organization and the input they are making.

\subsection{Conceptual Framework}

\begin{tabular}{|l|l|l|}
\hline $\begin{array}{l}\text { Talent attraction } \\
\text {-Branding } \\
\text {-Fair pay } \\
\text {-Work life balance } \\
\text {-Job security }\end{array}$ & $\begin{array}{c}\text { Organizational performance } \\
-\end{array}$ \\
\cline { 2 - 3 } & - & Customer satisfaction \\
\end{tabular}

Figure 1: Conceptual framework.

\subsection{RESEARCH METHODOLOGY}

\subsection{Research Design}

The study used descriptive research design. This design was chosen because it uses data collected from research questions to answer questions concerning current status of a phenomenon (Mugenda \& Mugenda, 2003). Mertler \& Charles (2005) argued that when dealing with people, situations and conditions about which we wish to know more, then descriptive survey is best. These arguments favor this study hence the choice of this design. The target population for the study was the Managers, academic and non-academic staff. Stratified random sampling technique was used through proportional allocation to ensure that all the strata are represented in the eventual sample. The validity and reliability of the research instrument was pilot tested to ascertain the validity and reliability. This research used both quantitative and qualitative methods. Qualitative helps to understand people's perceptions while quantitative focuses on prediction. .

\subsection{Sample Size}

A sample of 102 employees was selected for this study from the target population. This sample was chosen because it represented the entire population. The research ensured that all cadres of employees were represented. According to Israel (1992), the formulae for calculating the desired sample size is:

$\mathrm{n}=\mathrm{N} / 1+\mathrm{N}(\mathrm{e})^{2}$.

Where $\mathrm{n}=$ Desired sample size

$\mathrm{N}=$ Total Population.

$\mathrm{e}=$ Level of precision of 0.05

$$
\mathrm{n}=\frac{138}{1+138(0.05)^{2}} \quad=102
$$

\subsection{Data collection}

The structured questionnaire was used to collect the information from the employees of the universities at their work place. Where applicable the questionnaire was in the form of modified Linkert five point scale. A total of 89 questionnaires were returned, representing $87.25 \%$ return rate.

\subsection{Data Analysis}

Once the raw data had been collected, the first step was to clean the data for any inconsistencies. The coding of the data was the next step. Descriptive and inferential statistics were used to explain results of the findings. These included means, frequencies and percentages. Analysis was done using a computer programme, the Statistical Package for Social 
Sciences (SPSS). In addition, the researcher used Pearson correlation so as to determine the relationship between talent attraction (independent variable) and organizational performance (dependent variable).

\subsection{Results and Findings}

\subsubsection{Descriptive Statistics}

Descriptive statistical analysis was used to analyze talent management variable (talent attraction). In reference scaling (Likerts scale) used in the study design, 5 represented strongly agree, 4 represented agree, 3 represented Not sure, 2 represented disagree and 1 represented strongly disagree, therefore strongly disagree (1) was minimum, strongly agree (5) was maximum. The mean was analyzed based on the respondents choices scaled between strongly agree and strongly disagree as indicated in table 1

Table 1: Elements of Talent attraction

\begin{tabular}{|c|c|c|c|c|c|}
\hline Elements of Talent Attraction & $\mathrm{N}$ & Min & Max & Mean & Std. Dev. \\
\hline $\begin{array}{l}\text { The institution has built a good brand image which has enabled } \\
\text { it to attract the best talent }\end{array}$ & 89 & 1 & 5 & 4.04 & .878 \\
\hline $\begin{array}{l}\text { The university employs fair pay commensurate to employees } \\
\text { performance to attract talent }\end{array}$ & 89 & 1 & 5 & 3.64 & .932 \\
\hline $\begin{array}{l}\text { The institution during selection of its candidates uses selection } \\
\text { matrix to enable it to get the best talent }\end{array}$ & 89 & 2 & 5 & 3.92 & .829 \\
\hline The institution encourages its employees to undertake trainings & 89 & 2 & 5 & 4.11 & .872 \\
\hline $\begin{array}{l}\text { Work life balance has attracted most employees to the } \\
\text { institution }\end{array}$ & 89 & 1 & 5 & 3.47 & .927 \\
\hline $\begin{array}{l}\text { The institution offers job security to its employees as to attract } \\
\text { them }\end{array}$ & 89 & 1 & 5 & 4.16 & .865 \\
\hline $\begin{array}{l}\text { Employees enjoy good working relationship with their } \\
\text { colleagues }\end{array}$ & 89 & 2 & 5 & 4.12 & .671 \\
\hline Valid N (list wise) & 89 & & & & \\
\hline
\end{tabular}

From the tables it is evident that most of the respondents agreed with most of the aspects of talent attraction with a mean of approximately 4 (agree). However on work life balance most of the respondents were not sure whether this has attracted most employees to the institution with a mean of approximately 3(not sure). This could be attributed to the fact that most employees are married and could be experiencing family to work interference and also lack of awareness on how to balance work, career and family.

\section{Table 2: Elements of Organizational Performance}

\begin{tabular}{|c|c|c|c|c|c|}
\hline Elements of organization Performance & $\mathrm{N}$ & Min & Max & Mean & Std. Dev. \\
\hline Majority of the customers are satisfied with the services offered. & 89 & 1 & 5 & 3.62 & 1.071 \\
\hline $\begin{array}{l}\text { The institution has systems in place to receive customer suggestions } \\
\text { and feedback. }\end{array}$ & 89 & 1 & 5 & 3.66 & 0.941 \\
\hline $\begin{array}{l}\text { Involvement of employees in decision making in the institution has } \\
\text { improved the corporate image of the organization. }\end{array}$ & 89 & 1 & 5 & 3.53 & 0.918 \\
\hline I am satisfied with my current job. & 89 & 1 & 5 & 3.87 & 0.944 \\
\hline Performance Appraisal is done objectively. & 89 & 1 & 5 & 3.91 & 0.900 \\
\hline I am able to communicate effectively with clients. & 89 & 1 & 5 & 4.28 & 0.812 \\
\hline Employees are given incentives. & 89 & 1 & 5 & 3.36 & 1.100 \\
\hline There is effective service delivery in the institution. & 89 & 1 & 5 & 3.82 & 0.899 \\
\hline Valid N (list wise) & 89 & & & & \\
\hline
\end{tabular}

From the findings it's evident that most of the respondents agreed with most aspects of organizational performance with a mean of approximately 4 (agree). However respondents were indifferent on whether employees are given incentives with a mean of approximately 3(not sure). 


\subsection{Influence of Talent Attraction on Organizational Performance}

The first objective of the study was to determine the influence of talent attraction on organizational performance in Public University campuses in county government of Nakuru. The key elements of talent attraction on organizational performance in public university campuses in county government of Nakuru were: - the institution has built a good brand image which has enabled it to attract the best talent, the university employs fair pay commensurate to employees performance to attract talent, work life balance has attracted most employees to the institution and the institution offers job security to its employees as to attract them. The study used Pearson Correlation to establish the kind of relation that existed between talent attraction programs and Organizational performance

Table 3: Correlation between Talent Attraction and Organizational Performance

\begin{tabular}{lll}
\hline & & Organizational performance \\
\hline Talent attraction & Pearson Correlation & 0.640 \\
& Sig. (1-tailed) & 0.000 \\
$\mathrm{~N}$ & 89 \\
\hline
\end{tabular}

${ }^{* *}$ Correlation is significant at the 0.05 level (1-tailed).

Based on table 3 above, the results revealed that there was a strong statistically significant positive relationship of $(r=$ $0.640, p<0.05$ ) between talent attraction and Organizational performance. Therefore, this confirms the positive influence of talent attraction on organization performance in public university campuses in county government of Nakuru, and answers the first research question that talent attraction has significant effect on organization performance in public university campuses in county government of Nakuru. This concurs with Kelly, (2013) whose finding indicated components of talent attraction which includes salary package among others positively influence organizational performance.

\subsection{Summary, of the Findings}

Public Universities have increased over the past few years bring about stiff competition for the best talent. Talent attraction therefore plays a crucial role towards ensuring that an institution attracts the best talent as to gain competitive edge over other institutions. The main objective of this study is establish the influence of talent attraction on organizational performance.

\subsubsection{Findings on the influence of Talent Attraction}

Based on the results, it was established that institutions have built a good brand image which has enabled it to attract the best talent, employs fair pay commensurate to employees performance to attract talent and during selection of its candidates the institutions uses selection matrix to enable it to get the best talent. Finally it is important to note that based on the findings of the study that the institutions offers job security to its employees as to attract them. In broad-spectrum the results revealed that there is statistically significant positive relationship between talent attraction and organizational performance in public university campuses in county government of Nakuru, specified by strong positive correlation of $64.0 \%$.

\subsection{Conclusion}

The aim of the study was to determine the influence of talent attraction on Organizational Performance. Organizational Performance was studied in terms of customer satisfaction and service delivery. Based on the results from data analysis and findings in relation to the study objective, the following conclusion was made.

\subsubsection{Conclusion on Talent Attraction}

Talent attraction has statistically strong significant positive effect on organizational performance. This suggests that organizations are likely to enjoy significant improved organizational performance when they are able to attract the best talent trough various aspects of talent attraction like employer branding and ensuring that they commensurate their employees adequately.

\subsection{Recommendations for the study}

\subsubsection{Organizational Recommendations}

First organizations should come up with programs that create a balance between job demand and life outside work. This could involve introducing flexible working arrangements and creating awareness to ensure all employees are informed accordingly. With this it will attract new employees and reduce on stress and abseentism among employees. That organization should do proper succession planning as to ensure knowledge transfer and retention of expertise in the organization.

\subsubsection{Policy Recommendations}

As indicated from the findings of the study talent attraction programs improve/enhance the organizational performance in Public University Campuses, it is therefore necessary that public organizations implement/adopt talent attraction programs to improve their organizational performance. Different talent management programs should be adopted as per policies of 
the organizations and needs of the employees and these employees should be sensitized on the availability of the programmes and the accessibility of the programs to them. It is also important that HR departments in public universities/organizations be responsive to the needs and constantly changing requirements of workforce and the effect of environmental issues in order to improve and update policies as need be. This will enhance the organizational performance in Public institutions.

\subsection{Recommendations for further research}

This research was based on influence of talent attraction on organizational performance in Public University Campuses in County Government of Nakuru, Kenya. Basically there are other talent management programs available and they contribute more to organizational performance. Therefore there is need for more research to capture these programmes/factors to determine whether they have a significant positive effect on organizational performance in Public University Campuses or not..

The study focused on public universities campuses only. This limits the generalization of results. Similar studies needs to be conducted in private universities. A comparative study can also be done to capture the talent management programs adopted in public and private universities and their effect on organization performance and determine whether there is a difference in influence. This research selectively captured public universities campuses in Nakuru County only. A further research can be done to capture other public universities campuses in other counties to establish whether the findings will be the same

\section{REFERENCES}

1. AAPAM, (2008). Talent Management in Organizations. The African Association for Public Administration and Management. Conference Paper.

2. Armstrong, M. (2011). A handbook of Human Resource Management practices $\left(10^{\text {th }} \mathrm{Ed}\right)$.

a. London: Kogan Page Ltd.

3. Bano, Khan, M., \& Rehman, Q. (2011). Schematizing Talent Management a core business issue (A study of the factors that impact on talent management in the corporate sector of Islamabad Pakistan) Far East Research Centre Hong Kong. 2(1), 4-16.

4. Botha, A., Bussin, M., \& De Swart, L. (2011). An Employer Brand predictive model for Talent Attraction and Retention. SA Journal of Human Resource Management 9(1), 1-12

5. George, D., \& Malley, P. (2003). SPSS for Windows step by step: A simple guide and reference. 11.0 update $\left(4^{\text {th }}\right.$ Ed.). Boston: Allyn \& Bacon.

6. Gichuhi, D. Gakure, W., \& Waititu A, (2014). Talent Management its role on competitiveness of Public Universities in Kenya. Journal of Humanities and Social Sciences. 19(1) 100-105.

7. Iles, P.,Chuai, X. \& Preece, D. (2010). 'Talent Management and HRM in Multinational

8. Companies in Beijing: Definition, difference and drivers', Journal of World Business,

9. 45,179-189.

10. Israel, D. (1992). Determining Sample Size, Agricultural Education and Communication Department, University of Florida, IFAS Extension, PEOD6 (Reviewed 2013).

11. Jarad, I. Yusof., N. \& Nibkin, D. (2010). A Review Paper on Organizational Culture and Organizational Performance. International Journal of Business and Social Science. 1(3), 26-46.

12. Kamau, A. Gakure, R., \& Waititu, A. (2013). Influence on Institutional Leadership on Talent Management in Public Universities Kenya .Prime Journal of social sciences 2(1), 430- 437.

13. Kehinde, J. (2012). Talent management effect on organization performance .Journal of

a. Management Research 4 (2), 178-186.

14. Kellyservice, (2013). Attraction and Retention of Talent. Retrieved on 16th June 2015.

15. Kenani, D. (2011). 'Strategic options to human resource challenges in Geothermal
a. Operations in Kenya. Proceedings, Kenya Geothermal Conference 2011 Kenyatta
b. International Conference Centre, Nairobi.

16. Khatri, P. Gupta, S., \& Gulati, K. (2010). Talent Management in HR. Journal of Management and Strategy. 1(1) 39-46.

17. Lyria, R. (2013). Effect of Talent management on Organizational Performance in Companies Listed in
Nairobi Security Exchange Kenya. 3(21) 285-290. 


\section{ISSN 2278-5612}

18. Mertler, A. \& Charles, M. (2005). Introduction to Educational Research. (7 $7^{\text {th }}$ Ed.). Pearson Publishers.

19. Michington, B. (2010). The employer brand manager's handbook. Torrensville Collective Learning.

20. Mohammed, A, \& Mochorwa, K. (2015). The Impact of Talent management on Employee Engagement, Retention and value addition in achieving Organizational Performance. International journal of core Engineering \& Management 1(12), 142-152.

21. Mwangi, N. (2013): Factors influencing effective talent management strategy in organizations. A case of corrugated iron sheets limited Mombasa Kenya .European Journal of Business and Management 5(24), 113120.

22. Mugenda, O. \& Mugenda, A. (2003). Research Methods: Quantitative and Qualitative Approaches. Nairobi, ACTS press.

23. Onwuka, M. Ugwu, E. \& Kekecho, E. (2015), The relationship between talent management and employee performance in Nigeria Public Sector: A study of selected firms in delta state. Journals of Economics, Commerce and Management 3(5), 1561-1592.

Ozugner, Z. \& Ozugner, M. (2014). A Managerial point of view on the relationship between Maslow's Hierarchy of Needs and Herzberg's Dual Factor theory. International Journal of Business and Social Science. 4(5),779-790.

Rahimli, A. (2012). The Impact of Knowledge Sharing on Motivation Transfer Training of Employee. Interdisciplinary Journal of Contemporary research in Business, 5(14),69-93.

Saleemi, N. (2006). Principles and Practice of management simplified, Nairobi, Saleemi

Publication.

Scullion, H., Collings, D. G, \& Caligiuri, P. (2010). Global talent management Editorial, Journal of World Business. 45(2), 105-108.

Sokro, E. (2012). Impact of Employer Branding on Employee Attraction and Retention. European Journal of Business and Management 4(18) 114-140.

Veiman, V. \& Holden, N. (2011). "Talent Managements perplexing landscape in Central and Eastern Europe, In Scullion, H. and Collings, D.G. (Eds), Global Talent Management, Routledge London 178-193.

Yaqub, B., \& Khan, M. (2011). The role of employer branding and talent management for Organizational Success attractiveness. Far East Journal of Psychology and Business. 5(1), 57-65. 